\title{
Antimicrobial and anticancer activity of some novel fluorinated thiourea derivatives carrying sulfonamide moieties: synthesis, biological evaluation and molecular docking
}

\author{
Mostafa M. Ghorab ${ }^{1,2^{*}}$, Mansour S. Alsaid ${ }^{1}$, Mohamed S. A. El-Gaby ${ }^{3 *}$, Mahmoud M. Elaasser ${ }^{4}$ \\ and Yassin M. Nissan ${ }^{5}$
}

\begin{abstract}
Background: Various thiourea derivatives have been used as starting materials for compounds with better biological activities. Molecular modeling tools are used to explore their mechanism of action.

Results: A new series of thioureas were synthesized. Fluorinated pyridine derivative $\mathbf{4 a}$ showed the highest antimicrobial activity (with MIC values ranged from 1.95 to $15.63 \mu \mathrm{g} / \mathrm{mL}$ ). Interestingly, thiadiazole derivative $\mathbf{4 c}$ and coumarin derivative $\mathbf{4 d}$ exhibited selective antibacterial activities against Gram positive bacteria. Fluorinated pyridine derivative $\mathbf{4 a}$ was the most active against HepG2 with IC50 value of $4.8 \mu \mathrm{g} / \mathrm{mL}$. Molecular docking was performed on the active site of MK-2 with good results.

Conclusion: Novel compounds were obtained with good anticancer and antibacterial activity especially fluorinated pyridine derivative $\mathbf{4 a}$ and molecular docking study suggest good activity as mitogen activated protein kinase-2 inhibitor.
\end{abstract}

Keywords: Isothiocyanate, Sulfonamide, Fluorinated thiourea, Antimicrobial and anticancer activity

\section{Background}

Fluorinated compounds are intriguing for the development of pharmaceuticals, agrochemicals, and materials, and thus, much effort has been exerted to develop more general and efficient approaches for introducing fluorine atom(s) or fluoroalkyl group(s) into organic molecules [1-4]. The unique properties of fluoro organic molecules may arise from the properties such as (i) the greatest electronegativity of fluorine, (ii) the largest strength of the carbon-fluorine bond, (iii) the hardness and the low van der Waals interaction due to the low polarizability, (iv)

\footnotetext{
*Correspondence: mghorab@ksu.edu.sa; mmsghorab@yahoo.com; m_elgaby@hotmail.com

1 Pharmacognosy Department, College of Pharmacy, King Saud University, P.O. Box 2457, Riyadh 11451, Saudi Arabia

${ }^{3}$ Department of Chemistry, Faculty of Science, Al-Azhar University at Assiut, Assiut 71524, Egypt

Full list of author information is available at the end of the article
}

the increased hydrophobicity, and (v) the second smallest atomic radius of the fluorine atom. These factors are operative singly or sometimes cooperatively to affect the pharmacological properties of the fluorinated molecules [5]. The majority of fluorinated drugs are constructed by five- and six-membered nitrogen heterocycles containing fluorine, trifluoromethyl, difluoromethyl, fluoromethyl, 2,2,2-trifluoroethyl, and pentafluoroethyl groups [6]. An increasing number of fluorinated antimitotic/antitumour agents have now becoming available for cancer treatment. The most widely used are the 5-fluoropyrimidines such as 5-fluorouracil (5-FU) and 5-fluoro-2'-deoxyuridine (FdUrd) [7, 8], (Fig. 1). The thiourea derivatives represent one of the most promising classes of anticancer agents with a wide range of activities against various leukemia and solid tumors [9-17]. They play an important role as anticancer agents because of their good inhibitory activity against protein tyrosine kinases (PTKs), [10-13] 
<smiles>O=c1[nH]cc(F)c(=O)[nH]1</smiles>

5-Fluorourail<smiles>O=c1[nH]c(=O)n(C2CC(O)C(CO)O2)cc1F</smiles>

(FdUrd)<smiles>CC(C)CCOc1ccc(NC(=S)Nc2ccc(OCCC(C)C)cc2)cc1</smiles>

Thiocarlide<smiles>S=C(NCCc1ccccn1)Nc1nccs1</smiles>

PETT

(LY73497)

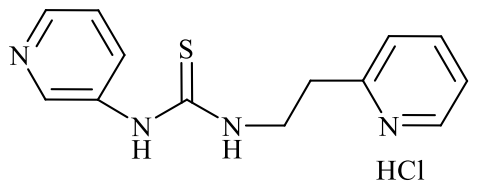

Trovirdin. $\mathrm{HCl}$ (LY300046)

Fig. 1 Fluorinated and thiourea anticancer agents

human sirtuin type proteins 1 and 2 (SIRT1 and SIRT2), [14] topoisomerase II [15] and DNA repair synthesis [16]. Furthermore, fluorinated aryl thioureas represent a new class of potent anti-trypanosomal agents [18] and also a novel class of potent influenza virus neuraminidase inhibitors [19]. Thiocarlide is a pharmacologically important thiourea drug that is used as a therapeutic agent in the treatment of tuberculosis [20] and Phenethylthiazoylthiourea (PETT) derivatives (LY73497 and trovirdine $\mathrm{HCl}$ ) [21, 22] have been discovered as potent inhibitors of HIV type 1, (Fig. 1).

Literature survey revealed that sulfonamides are a significant class of compounds in medicinal and pharmaceutical chemistry with several biological applications [23]. Today, they are widely used as antimicrobial agent, chiefly because of their low cost, low toxicity and excellent activity against bacterial diseases [24]. Some important sulfonamide derivatives used as carbonic anhydrase inhibitors of commercial importance [25]. They are also effective for the treatment of urinary, intestine, and ophthalmic infections, scalds, ulcerative colitis [26], rheumatoid arthritis [27], male erectile dysfunction as the phosphodiesterase-5 inhibitor sildenafil-better known under its commercial name, Viagra [28], and obesity [29]. More recently, sulfonamides are used as an anticancer agent [30], as the antiviral HIV protease inhibitor amprenavir [31] and in Alzheimer's disease [32]. Prompted by the above facts and in continuation of our interest in biologically active compounds [33-35] we hereby report the synthesis of some novel of fluorinated $N$-(2,6-dimethoxypyrimidin-4-yl)-4-(3-(aryl)thioureido) benzenesulfonamides $3 \mathbf{a}-\mathbf{e}$ and $\mathbf{4 a}-\mathbf{d}$ from readily available starting material to evaluate their antimicrobial and anticancer activity.

\section{Results and discussion Chemistry}

Isothiocyanates are useful and widely used building blocks in the synthesis of nitrogen, sulfur and oxygen heterocycles and organometallic compounds of academic, pharmaceutical and industrial interest [36]. The high electrophilicity and nucleophilicity associated with the carbon and sulfur atoms, respectively, of the isothiocyanates and their extended $\pi$ electron system make them unique precursors of a large variety of target molecules. Consequently, many classes of five and six-membered nitrogen and sulfur heterocycles, either carrying various substituents or fused with benzo or non-benzo nuclei to interesting poly heterocycles, have been synthesized from isothiocyanates which is undoubtedly a landmark in organosulfur chemistry [37]. The intermediate, $\quad N$-(2,6-dimethoxypyrimidin-4-yl)-4-isothiocyanatobenzenesulfonamide 2 used for the preparation of target compounds have been synthesized in high yield via thiophosgenation of sulfa-dimethoxazine $\mathbf{1}$ at room temperature in the presence of dilute hydrochloric acid, according to literature procedure [38] (Scheme 1).

The synthesis of $N$-(2,6-dimethoxypyrimidin-4-yl)4-(3-(aryl) thio-ureido)benzenesulfonamides $\mathbf{3 a}-\mathbf{e}$ is outlined in Scheme 2. Treatment of isothiocyanato benzenesulfonamide $\mathbf{2}$ with a variety of fluorinated aromatic amines in dry dioxane at reflux temperature in 


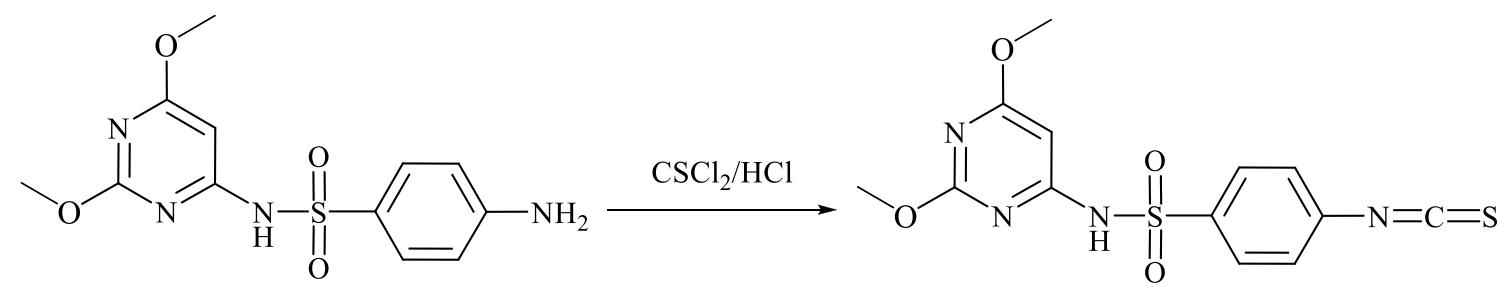

(1)

(2)

Scheme 1 Synthesis of N-(2,6-dimethoxypyrimidin-4-yl)-4-isothiocyanato-benzenesulfonamide $\mathbf{2}$

the presence of a catalytic amounts of triethylamine furnished the novel fluorinated $N, N$-disubstituted thioureas 3a-e in high yields (80-92\%).The structure of the products $3 \mathbf{a}-\mathbf{e}$ were established via inspection of their spectral data. Thioureas 3a-e were confirmed by the absence of characteristic infrared absorption peak at $2000-2200 \mathrm{~cm}^{-1}(\mathrm{~N}=\mathrm{C}=\mathrm{S}$ group). Also, the infrared of 3 is characterized by the presence of the $\mathrm{NH}, \mathrm{CN}$, thiocarbonyl (CS) and $\mathrm{SO}_{2}$ absorption bands. For example, the ${ }^{1} \mathrm{H}$ NMR of compound 3a showed two singlets at $\delta 3.81$, $3.84 \mathrm{ppm}$ which were assigned for two methoxy protons, a singlet at $\delta 5.9 \mathrm{ppm}$ assigned to the pyrimidine$\mathrm{H}$, two downfield singlets at $\delta 11.8$, and $14.0 \mathrm{ppm}$ which were readily assigned to the $\mathrm{HN}(1)$ and $\mathrm{HN}(2)$ protons, in addition to the presence of $\mathrm{SO}_{2} \mathrm{NH}$ and aromatic protons. The thiocarbonyl group of thiourea moiety was also observed in ${ }^{13} \mathrm{C}$-NMR. The formation of thiourea $3 \mathbf{a}-\mathbf{e}$ can be explained by the reaction pathway depicted in Fig. 2.

The nucleophilic attack of the amino group of the aromatic amine on thiocarbonyl group of isothiocyanate leads to formation of an intermediate (A). During the consecutive steps, deprotonation and protonation of the intermediate results in the formation of the final product thiourea. Under similar reaction conditions, treatment of isothiocyanate $\mathbf{2}$ with fluorinated heterocyclic amines such as 2-amino-2,3,5,6-tetrafluoropyridine, 2-amino6-fluorobenzothiazole, 2-amino-5-(trifluoromethyl)-1,3,4thiadiazole and 7-amino-4-(trifluoromethyl)-coumarine afforded the corresponding fluorinated heterocyclic thioureas $\mathbf{4 a - d}$, (Scheme 3). The composition and structure of products $\mathbf{4 a - d}$ were confirmed by the results of elemental analysis and data of IR and NMR spectra. The infrared of structure 4 displayed absorption band assignable for $\mathrm{NH}$, thiocarbonyl (CS) and $\mathrm{SO}_{2}$ groups. The infrared of $\mathbf{4 c}$ exhibited stretching frequencies at 3415, 3310, 2978, 2841 and $1618 \mathrm{~cm}^{-1}$ for the two $\mathrm{NH}, \mathrm{CH}$-aliph and $\mathrm{CN}$ groups, in addition to the presence of absorption bands corresponding to $\mathrm{SO}_{2}$ and $\mathrm{CS}$ at $1311,1195,1274 \mathrm{~cm}^{-1}$. Its ${ }^{1} \mathrm{H}$
NMR showed two singlets at $\delta 3.64,3.66 \mathrm{ppm}$ which were assigned for two methoxy protons, a singlet at $\delta 6.5 \mathrm{ppm}$ assigned to the pyrimidine- $\mathrm{H}$, two downfield singlets at $\delta 11.8$, and $12.4 \mathrm{ppm}$ which were readily assigned to the $\mathrm{HN}(1)$ and $\mathrm{HN}(2)$ protons, in addition to the presence of $\mathrm{SO}_{2} \mathrm{NH}$ and aromatic protons (Scheme 3).

\section{Antimicrobial evaluation}

The newly synthesized target compounds were evaluated for their in vitro antibacterial activity against Streptococcus pneumoniae and Bacillus subtilis as examples of Gram-positive bacteria and Pseudomonas aeruginosa and Escherichia coli as examples of Gram-negative bacteria. They were also evaluated for their in vitro antifungal potential against a representative panel of fungal strains i.e. Aspergillus fumigatus, and Candida albicans. The organisms were tested against the activity of solutions of concentrations $(1 \mathrm{mg} / \mathrm{mL})$ and using inhibition zone diameter in $\mathrm{mm}$ as criterion for the antimicrobial activity (agar well diffusion method). The results of testing for antibacterial and antifungal effects are summarized in Table 1 . As shown by these results, the newly synthesized compounds tested displayed variable in vitro antibacterial and antifungal activities.

From the screening results, it can be seen that compound 4a showed the highest activity against Gram positive bacteria $B$. subtilis followed by compounds 4c, 4d, 3d and 4b, respectively. Similarly, compound 4a showed the highest activity against Gram positive bacteria $S$. pneumoniae followed by compounds $4 d$, 3d, $\mathbf{4 c}$, and $\mathbf{4 b}$, respectively using ampicillin as reference drug. Compound 4a showed inhibition zone of $20.6 \pm 1.5 \mathrm{~mm}$ in case of S. pneumoniae compared to inhibition zone of $23.8 \pm 0.6 \mathrm{~mm}$ attributed to ampicillin while in case of B. subtilis, compound 4a showed inhibition zone of $22.1 \pm 1.2 \mathrm{~mm}$ compared to inhibition zone of $26.4 \pm 0.7 \mathrm{~mm}$ due to ampicillin. On the other hand, compound 4a showed the highest activity against Gram negative bacteria ( $P$. aeruginosa and E. coli) compared 


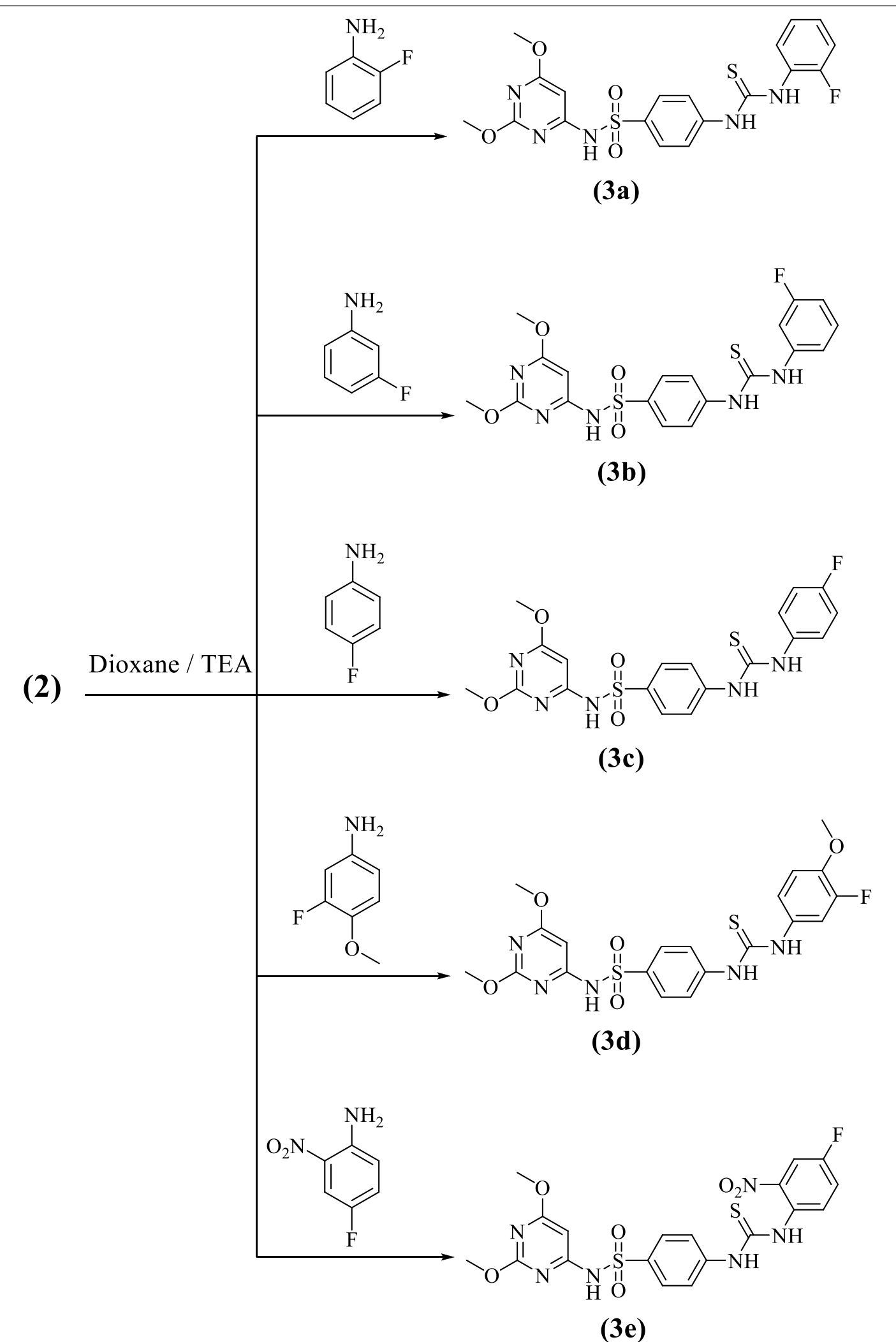

Scheme 2 Synthetic route and structures for thiourea derivatives (3a-e) 


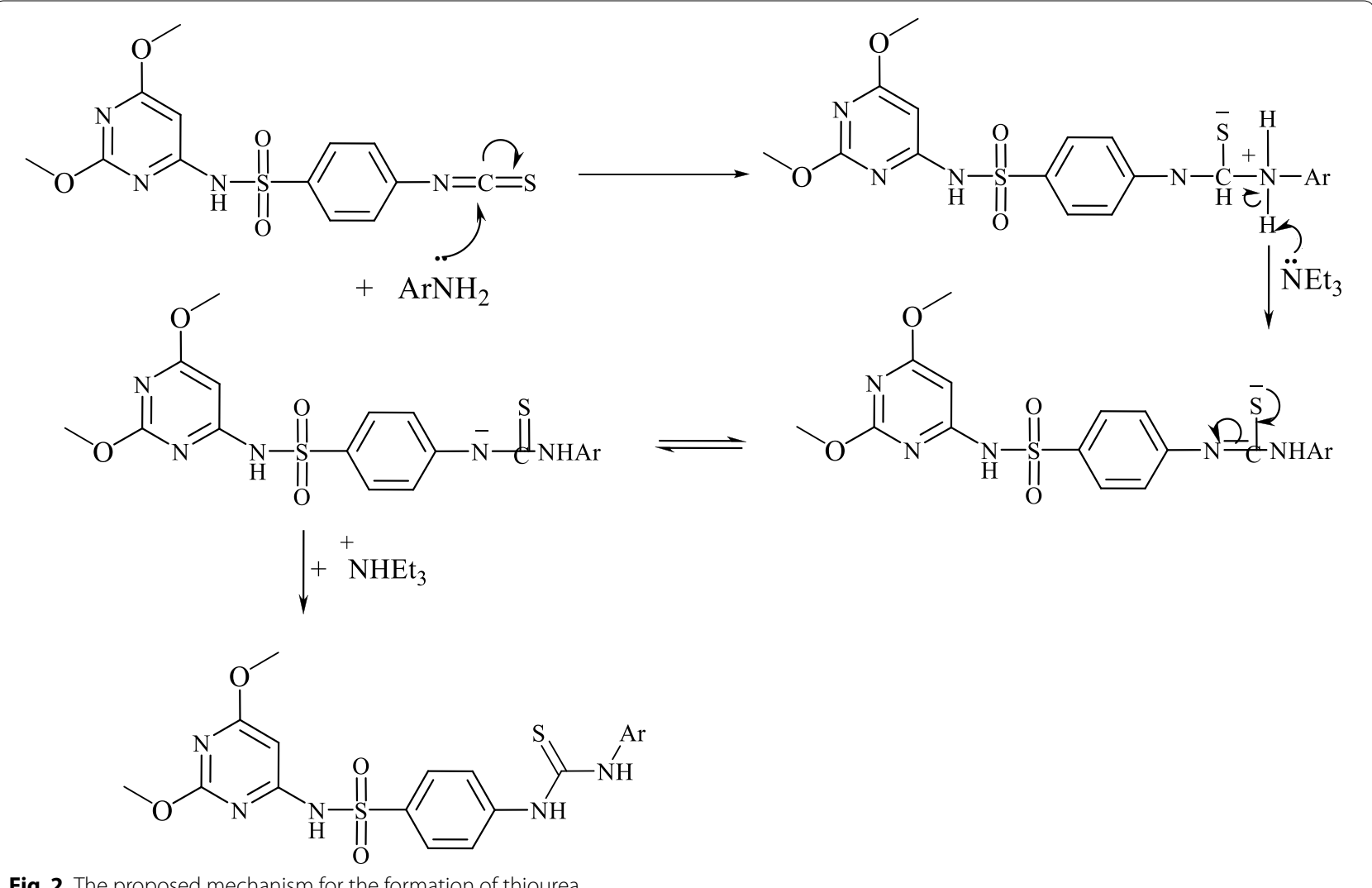

Fig. 2 The proposed mechanism for the formation of thiourea

with the standard drug followed by compounds $\mathbf{3 d}$, and $4 \mathbf{b}$, respectively. Compound $4 \mathbf{a}$ showed inhibition zone of $17.2 \pm 1.5 \mathrm{~mm}$ in case of $P$. aeruginosa compared to inhibition zone of $19.7 \pm 0.6 \mathrm{~mm}$ attributed to gentamycin while in case of $E$. coli, compound 4a showed inhibition zone of $21.3 \pm 0.8 \mathrm{~mm}$ compared to inhibition zone of $24.9 \pm 1.5 \mathrm{~mm}$ due to gentamycin. Interestingly, compounds $\mathbf{4 c}$ and $\mathbf{4 d}$ exhibited selective antibacterial activities against Gram positive bacteria.

Regarding the activity of the tested compounds against the tested filamentous fungus A. fumigatus, the order of activity $\mathbf{4 a}, \mathbf{3 d}$, and $\mathbf{4 b}$. No antimicrobial activities were detected for compounds 3a, 3c and 3e. Also, none of the tested compound exerts any activity against the pathogenic yeast species ( $C$. albicans) under these screening conditions. Compound $4 \mathbf{a}$ was the most active compound in this case also. Compound 4a showed inhibition zone of $20.1 \pm 1.3 \mathrm{~mm}$ compared to $23.7 \pm 1.2 \mathrm{~mm}$ exhibited by amphotrecin B. The antimicrobial activities of the most active synthesized fluorinated compounds were also tested to determine the minimum inhibitory concentration (Table 2). Moreover, compound 4a showed the highest activity (MIC values ranged from 1.95 to $15.63 \mu \mathrm{g} / \mathrm{mL}$ ), followed by $3 \mathrm{~d}$ (MIC 7.81-250 $\mu \mathrm{g} / \mathrm{mL}$ ) and 4b (MIC $7.81-250 \mu \mathrm{g} / \mathrm{mL}$ ).

\section{Structure activity relationship}

Regarding activity against Gram positive bacteria, mono substituted fluorophenyl derivatives $\mathbf{3 a}-\mathbf{3} \mathbf{c}$ showed no activity also the nitro fuolorinated derivative $3 \mathbf{e}$ was also inactive. The best activity was attributed to tetrafluoro pyridine derivative $4 a$ indicating that increasing the number of fluoro substitutions has good impact on activity followed by trifluoromethyl derivatives $\mathbf{4 c}$ and $\mathbf{4 d}$ with tri fluoro substitution and finally the fluoro methoxy derivative $\mathbf{3 d}$ and the fluorinated benzothiazole derivative $\mathbf{4 b}$. Similarly, The tetrafluoro pyridine derivative $\mathbf{4 a}$ was the most active compound on Gram negative bacteria. Also in case of antifungal activity the tetrafluoro pyridine derivative 4a was the most active compound.

\section{Cytotoxic activity}

The in vitro growth inhibitory activity of the synthesized compounds was investigated in comparison with the well-known anticancer standard drugs (5-flourouracil and cisplatin) under the same conditions using colorimetric MTT assay. Data generated were used to plot a dose response curve of which the concentration of test compounds required to kill $50 \%$ of cell population $\left(\mathrm{IC}_{50}\right)$ was determined (Fig. 3). The results revealed that all the tested compounds showed inhibitory activity to 


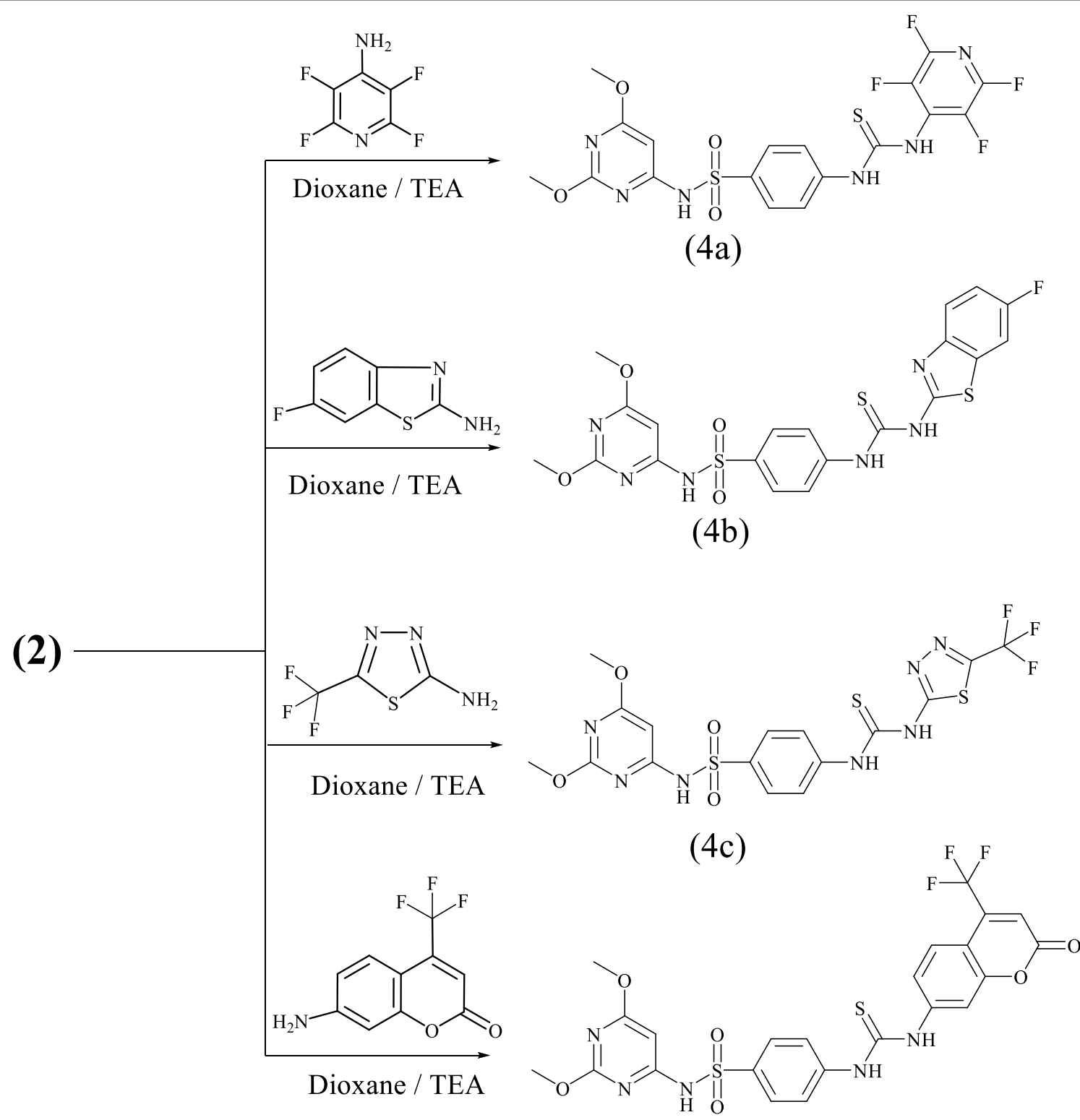

$(4 d)$

Scheme 3 Synthetic route and structures for thiourea derivatives (4a-d)

the tumor cell lines in a concentration dependent manner. Cytotoxic activity was expressed as the mean $\mathrm{IC}_{50}$ of three independent experiments.

Interestingly, the results are represented in Table 3 and Fig. 3 showed that compound $4 \mathbf{a}$ was the most active against the liver carcinoma cell line (HepG2), showing more activity than the reference drugs with $\mathrm{IC}_{50}$ value of $4.8 \mu \mathrm{g} / \mathrm{mL}$ compared to 5 -flourouracil with $\mathrm{IC}_{50}$ value of $4.9 \mu \mathrm{g} / \mathrm{mL}$ and cisplatin with $\mathrm{IC}_{50}$ value of $18.8 \mu \mathrm{g} / \mathrm{mL}$. Compound 3c exhibited good antitumor activity against the liver carcinoma cell line (HepG2) showing almost the same activity as cisplatin followed by $\mathbf{4 b}, \mathbf{4} \mathbf{c}, \mathbf{3 d}$ and $\mathbf{3 a}$, respectively. The tested compounds showed lower tendency to inhibit the breast carcinoma cells than those observed for liver carcinoma (Fig. 4). The order of activity against breast carcinoma cell line (MCF-7) was $\mathbf{4 a}, \mathbf{3 c}, \mathbf{4 b}$, and $\mathbf{4 c}$, respectively. Moreover, compounds 3a, 3d, $\mathbf{3 e}$ and $\mathbf{4 d}$ were less active among their analogues against the two tumor cell lines.

\section{Molecular docking}

One of the most important enzymes that controls signal transduction and cell proliferation is mitogen-activated 
Table 1 In vitro antimicrobial activities of the synthesized fluorinated compounds tested at $1 \mathrm{mg} / \mathrm{mL}$ by well diffusion agar assay and expressed as inhibition zone diameter $(\mathrm{mm})$ in the form of mean \pm SD

\begin{tabular}{|c|c|c|c|c|c|c|}
\hline \multirow{2}{*}{$\begin{array}{l}\text { Tested microorganisms } \\
\text { compound code }\end{array}$} & \multicolumn{2}{|l|}{ Fungi } & \multicolumn{2}{|c|}{ Gram positive bacteria } & \multicolumn{2}{|c|}{ Gram negative bacteria } \\
\hline & $\begin{array}{l}\text { A. fumigatus } \\
\text { RCMB } 002568\end{array}$ & $\begin{array}{l}\text { C. albicans } \\
\text { RCMB } 005036\end{array}$ & $\begin{array}{l}\text { S. pneumoniae } \\
\text { RCMB } 010010\end{array}$ & $\begin{array}{l}\text { B. subtilis } \\
\text { RCMB } 010067\end{array}$ & $\begin{array}{l}\text { P. aeruginosa } \\
\text { RCMB } 010043\end{array}$ & $\begin{array}{l}\text { E. coli } \\
\text { RCMB } 010052\end{array}$ \\
\hline $3 a$ & 0 & 0 & 0 & 0 & 0 & 0 \\
\hline $\mathbf{3 b}$ & 0 & 0 & 0 & 0 & 0 & 0 \\
\hline $3 c$ & 0 & 0 & 0 & 0 & 0 & 0 \\
\hline 3d & $16.9 \pm 1.2$ & 0 & $15.4 \pm 0.8$ & $18.2 \pm 0.6$ & $12.4 \pm 0.8$ & $15.1 \pm 1.2$ \\
\hline $3 e$ & 0 & 0 & 0 & 0 & 0 & 0 \\
\hline $4 a$ & $20.1 \pm 1.3$ & 0 & $20.6 \pm 1.5$ & $22.1 \pm 1.2$ & $17.2 \pm 1.5$ & $21.3 \pm 0.8$ \\
\hline $\mathbf{4 b}$ & $16.3 \pm 0.5$ & 0 & $14.2 \pm 0.4$ & $17.1 \pm 0.6$ & $11.2 \pm 0.7$ & $13.4 \pm 0.7$ \\
\hline $4 c$ & 0 & 0 & $15.1 \pm 0.7$ & $19.8 \pm 1.1$ & 0 & 0 \\
\hline 4d & 0 & 0 & $16.3 \pm 1.2$ & $18.3 \pm 0.8$ & 0 & 0 \\
\hline Amphotricin B & $23.7 \pm 1.2$ & $25.4 \pm 1.1$ & & & & \\
\hline Ampicillin & & & $23.8 \pm 0.6$ & $26.4 \pm 0.7$ & & \\
\hline Gentamycin & & & & & $19.7 \pm 0.6$ & $24.9 \pm 1.5$ \\
\hline
\end{tabular}

Table 2 The antimicrobial activities of the most active synthesized fluorinated compounds expressed as minimum inhibitory concentration $(\mu \mathrm{g} / \mathrm{mL})$

\begin{tabular}{llllll}
\hline Compound code & $\begin{array}{l}\text { A. fumigatus } \\
\text { RCMB 002568 }\end{array}$ & $\begin{array}{l}\text { S.pneumoniae } \\
\text { RCMB 010010 }\end{array}$ & $\begin{array}{l}\text { B. subtilis } \\
\text { RCMB 010067 }\end{array}$ & $\begin{array}{l}\text { P. aeruginosa } \\
\text { RCMB 010043 }\end{array}$ & $\begin{array}{l}\text { E. coli } \\
\text { RCMB 010052 }\end{array}$ \\
\hline 3d & 15.63 & 62.5 & 7.81 & 250 & 62.5 \\
$\mathbf{4 a}$ & 3.9 & 3.9 & 1.95 & 15.63 & 3.9 \\
$\mathbf{4 b}$ & 62.5 & 125 & 15.63 & 250 & 125 \\
Amphotricin B & 1.95 & - & - & - & - \\
Ampicillin & - & 0.98 & 0.49 & - & - \\
Gentamycin & - & - & - & 3.9 & 0.98 \\
\hline
\end{tabular}
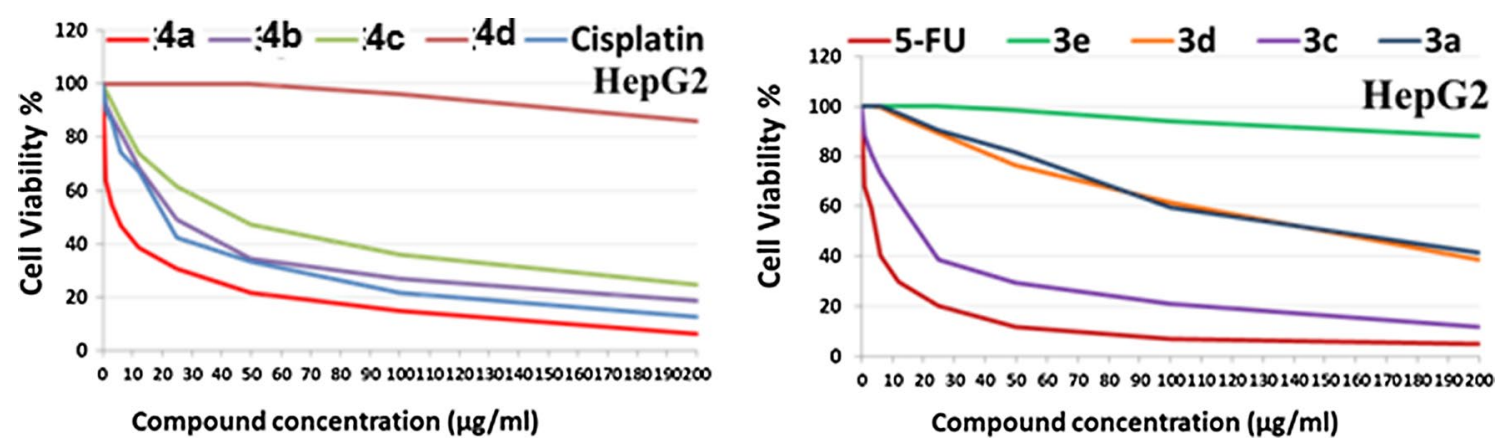

Fig. 3 The dose response curve showing the in vitro inhibitory activity of the tested compounds against liver carcinoma (HepG2) cell line compared with reference drugs cisplatin and 5-flourouracil

protein kinase-activated protein kinase 2 (MAPKAPK-2 or MK-2) [39]. Discovering new inhibitors for this key enzyme has received attention as a strategy in the seek for novel anticancer agents [40]. Among the newly discovered inhibitors for this enzyme, several urea and thiourea derivatives have showed good activity [41]. In the present research, several thiourea derivatives were synthesized and evaluated for their cytotoxic activity. The most active derivatives $3 \mathbf{c}$ and $\mathbf{4 a}-\mathbf{4} \mathbf{c}$ were docked on the active site of MK-2 enzyme in a trial to suggest a mechanism 
Table 3 The antitumor activities of the tested compounds expressed as $I_{50}$ values and compared with reference standard drugs evaluated on breast and liver cancer cell lines

\begin{tabular}{|c|c|c|}
\hline \multirow[t]{2}{*}{ Tested compounds } & \multicolumn{2}{|c|}{$\begin{array}{l}I C_{50} \text { values }(\mu \mathrm{g} / \mathrm{mL}) \text { against tumor } \\
\text { cell lines }\end{array}$} \\
\hline & MCF-7 & HepG2 \\
\hline $3 a$ & $>200$ & $153.1 \pm 2.3$ \\
\hline $3 \mathbf{b}$ & NA & NA \\
\hline $3 c$ & $41.9 \pm 1.7$ & $18.8 \pm 1.1$ \\
\hline 3d & $>200$ & $150.9 \pm 3.7$ \\
\hline $3 e$ & $>200$ & $>200$ \\
\hline $4 a$ & $22.3 \pm 1.5$ & $4.8 \pm 0.6$ \\
\hline $4 b$ & $46.1 \pm 1.6$ & $24.5 \pm 1.2$ \\
\hline $4 c$ & $63.8 \pm 1.2$ & $45.2 \pm 1.4$ \\
\hline 4d & $>200$ & $>200$ \\
\hline 5-flourouracil & $5.2 \pm 0.5$ & $4.9 \pm 0.3$ \\
\hline Cisplatin & $19.1 \pm 0.7$ & $18.8 \pm 0.6$ \\
\hline
\end{tabular}

of action for their cytotoxic activity. The protein data bank file (PDB: 3WI6). The file contains MK-2 enzyme co-crystalized with an inhibitor. All docking procedures were achieved by MOE (Molecular Operating Environment) software 10.2008 provided by chemical computing group, Canada. The inhibitor interacts with MK-2 active site with four hydrogen bonds involving Glu 190, Leu 141, Asn 191 ans Asp 207 (Fig. 5). The docking protocol was validated by redocking of the ligand on the active site of MK-2 enzyme with energy score $(S)=-15.4978 \mathrm{kcal} /$ mol and root mean square deviation $(\mathrm{RMSD})=1.1457$.

The previous docking protocol was followed for compounds $3 \mathbf{c}$ and $4 \mathbf{a}-\mathbf{4 c}$. All the docked compounds were fit on the active site of MK-2 enzyme. Docking scores and amino acid interactions for the docked compounds were summarized in Table 4.

On a closer look on Table 4 we can conclude that: all four compounds showed docking score better than the co-crystallized ligand in the range of $(-16.2293$ to $22.9000 \mathrm{kcal} / \mathrm{mol})$. The best docking score was displayed by compound $4 \mathbf{c}$ (Fig. 6).

In case of amino acid interactions, compound $4 \mathbf{a}$ is the only compound that exhibited two interactions with Leu 141 and Asp 207 by two hydrogen bond of 2.96 and 2.22 $\AA$, respectively (Fig. 7) which may explain its promising cytotoxic activity.

\section{Conclusion}

In conclusion, synthesis, structural elucidation, antimicrobial and anticancer activities of a new series of $N$-(2,6-dimethoxypyrimidin-4-yl)-4-(3-(aryl) thioureido) benzenesulfonamides $\mathbf{3 a}-\mathbf{e}$ and $\mathbf{4 a}-\mathbf{d}$ were reported. Compound 4a was the most active compound against Gram positive bacteria (B. subtilis and S. pneumoniae), Gram negative bacteria (P. aeruginosa and E. coli) and fungi (A. fumigatus). Interestingly, compounds $\mathbf{4 c}$ and $\mathbf{4 d}$ were selective to Gram positive bacteria. Compound 4a was the most active compound in cytotoxic assay against breast cancer cell line (MCF-7) and hepatic cancer cell line (HepG2). Compound 4a was more active than the standard drug 5-flourouracil in case of hepatic cancer cell line (HepG2). Molecular docking of compound 4a on the active site of mitogen activated kinase (MK-2) revealed good amino acid interactions.

\section{Experimental}

\section{General chemistry}

Melting points (uncorrected) were determined in an open capillary in a Gallenkamp melting point apparatus (Sanyo Gallenkamp, UK). Pre coated silica gel plates (Kieselgel 0.25 mm, 60 F254, Merck, Germany) were used for thin layer chromatography. A developing solvent system of chloroform/methanol (8:2) was used and the spots were detected by ultraviolet light. IR spectra ( $\mathrm{KBr}$ disc) were recorded using an FT-IR spectrophotometer (Perkin Elmer, USA). ${ }^{1} \mathrm{H}$ NMR spectra were scanned on an NMR spectrophotometer (Bruker AXS Inc., Switzerland),
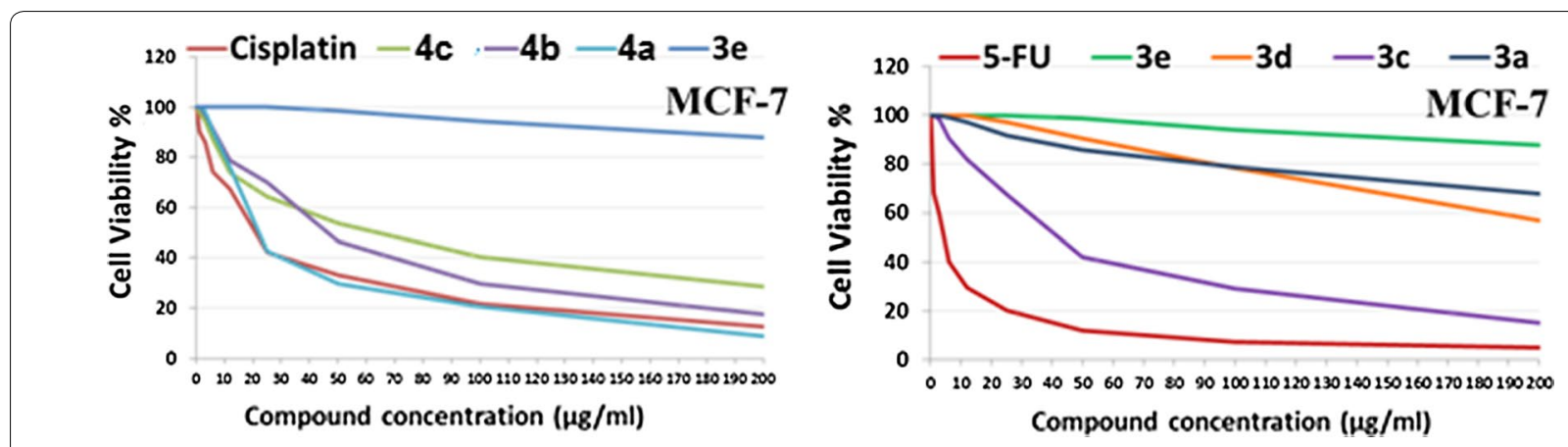

Fig. 4 The dose response curve showing the in vitro inhibitory activity of the tested compounds against breast carcinoma (MCF-7) cell line compared with reference drugs cisplatin and 5-flourouracil 


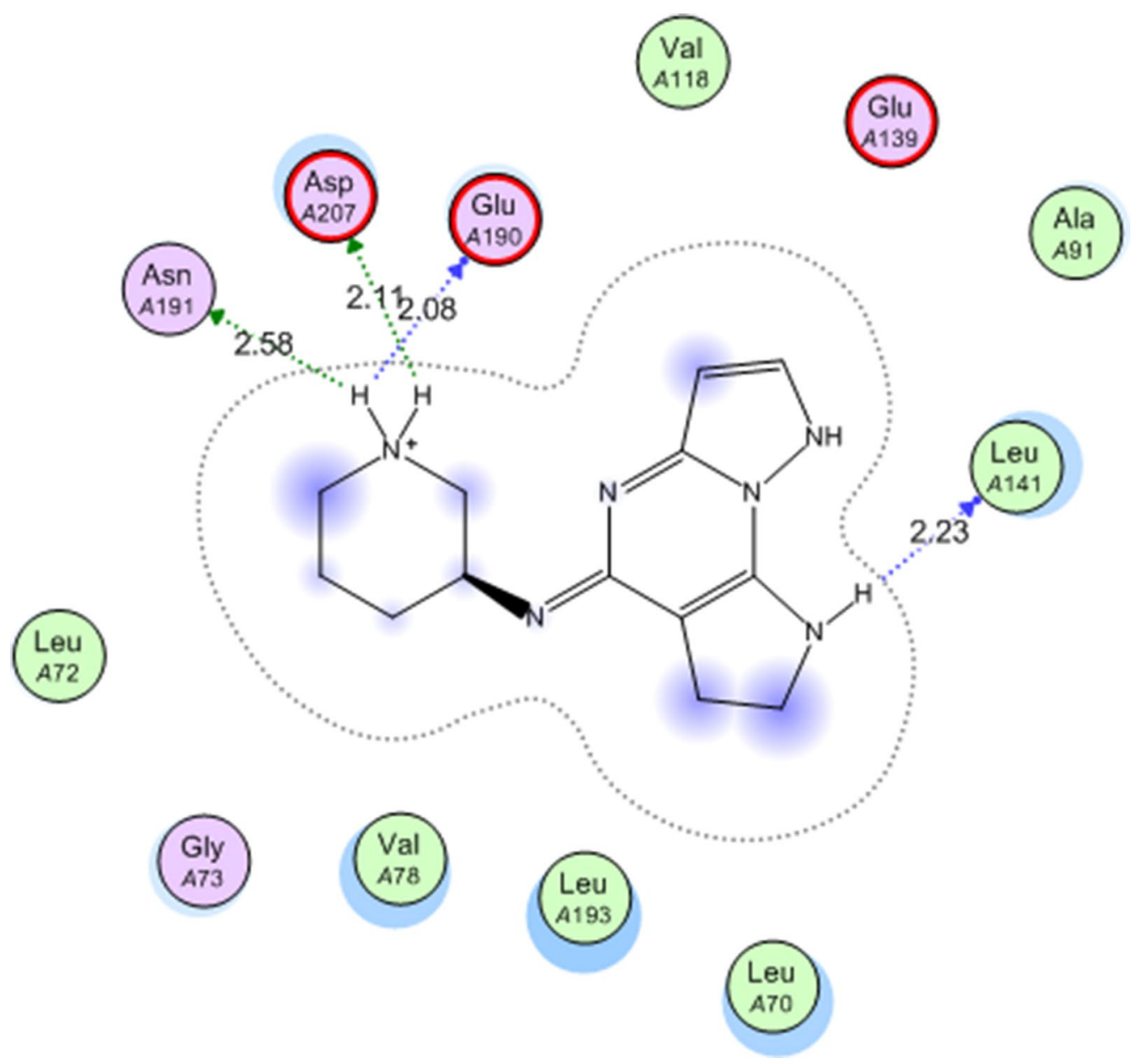

Fig. 5 Co-crystallized ligand in the active site of mitogen activated kinase (MK-2)

Table 4 Docking scores and amino acid interactions of the docked compounds on the active site of mitogen activated kinase (MK-2)

\begin{tabular}{|c|c|c|c|c|c|}
\hline Compounds & (S) $\mathrm{Kcal} / \mathrm{mol}$ & Amino acid & Interacting group & Type of interaction & H-bond length $(\AA)$ \\
\hline $3 c$ & -18.8805 & Asp 207 & $\mathrm{NH}$ & $\mathrm{H}$ bond (donor) & 1.25 \\
\hline $4 a$ & -20.8063 & $\begin{array}{l}\text { Leu } 141 \\
\text { Asp } 207\end{array}$ & $\begin{array}{l}\mathrm{SO}_{2} \\
\mathrm{NH}\end{array}$ & $\begin{array}{l}\mathrm{H} \text { bond (acceptor) } \\
\mathrm{H} \text { bond (donor) }\end{array}$ & 2.22 \\
\hline $4 b$ & -16.2293 & Asp 207 & $\mathrm{NH}$ & $\mathrm{H}$ bond (donor) & 2.12 \\
\hline $4 c$ & -22.9000 & Asp 207 & $\mathrm{NH}$ & $\mathrm{H}$ bond (donor) & 1.53 \\
\hline
\end{tabular}

operating at $500 \mathrm{MHz}$ for ${ }^{1} \mathrm{H}$ - and $125.76 \mathrm{MHz}$ for ${ }^{13} \mathrm{C}$ NMR. Chemical shifts are expressed in $\delta$ values (ppm) relative to TMS as an internal standard, using DMSO- $d_{6}$ as a solvent. Elemental analyses were done on a model 2400 CHNSO analyser (Perkin Elmer, USA). All values were within $\pm 0.4 \%$ of the theoretical values. All reagents used were of AR grade.
General procedure for $\mathrm{N}$-(2,6-dimethoxypyrimidin-4-yl)-4-(3- (aryl) thioureido)benzenesulfonamides 3a-e and $4 a-d$

To a mixture of isothiocyanatobenzenesulfonamide $\mathbf{2}$ $(0.01 \mathrm{~mol})$ and fluorinated aromatic amine $(0.01 \mathrm{~mol})$ in dioxane $(30 \mathrm{~mL})$, triethylamine $(0.1 \mathrm{~mL})$ was added. The reaction mixture was heated under reflux for $1 \mathrm{~h}$. The 


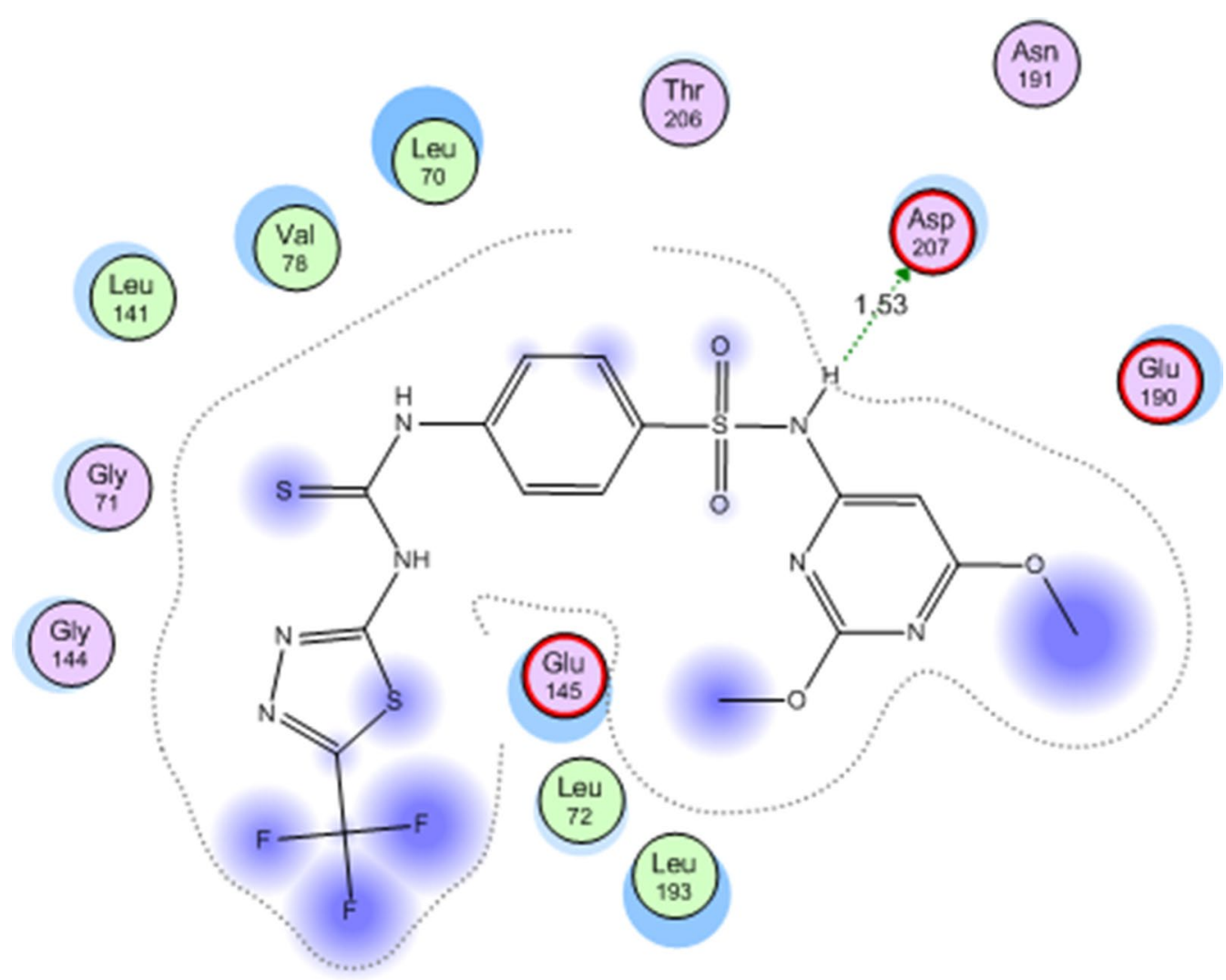

Fig. $\mathbf{6}$ Compound $\mathbf{4} \mathbf{c}$ in the active site of mitogen activated kinase (MK-2)

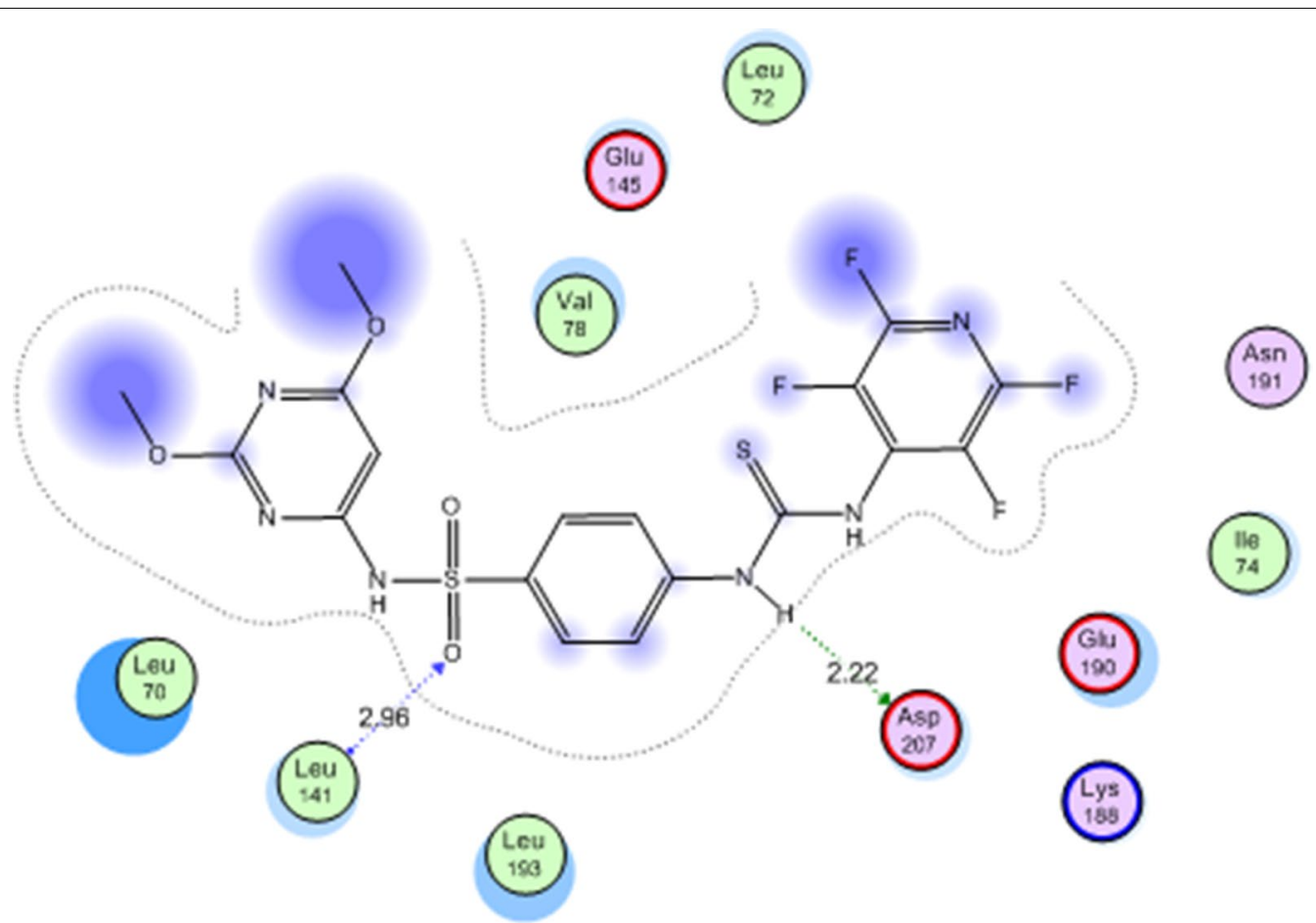

Fig. $\mathbf{7}$ Compound $\mathbf{4} \mathbf{c}$ in the active site of mitogen activated kinase (MK-2) 
solvent was removed by evaporation under reduced pressure and the remainder was left to cool. The solid product so formed was collected by filtration, washed with petroleum ether (bp $40-60{ }^{\circ} \mathrm{C}$ ) and the crude product recrystallized from ethanol to afford thiourea derivatives.

\section{N-(2, 6-Dimethoxy-pyrimidin-4-yl)-4-[3-(2-fluoro-phenyl) -thioureido]enzene-sulfonamide (3a)}

This compound was obtained as brown crystals from ethanol; yield 83\%; m.p. $348.1{ }^{\circ} \mathrm{C}$. IR: 3444, 3354, $3232(\mathrm{NH}), 3091$ (arom.), 2956, 2810 (aliph.), $1568(\mathrm{CN}), 1361,1180\left(\mathrm{SO}_{2}\right)$, 1265 (CS). ${ }^{1} \mathrm{HNMR}: \delta 3.81,3.84\left[2 \mathrm{~s}, 6 \mathrm{H}, 2 \mathrm{OCH}_{3}\right], 5.9[\mathrm{~s}, 1 \mathrm{H}$, $\mathrm{H}$ - pyrimidine], $6.7-8.0[\mathrm{~m}, 8 \mathrm{H}, \mathrm{Ar}-\mathrm{H}], 10.2\left[\mathrm{~s}, 1 \mathrm{H}, \mathrm{SO}_{2} \mathrm{NH}\right.$, 11.8, 14.0 [2 s, $2 \mathrm{H}, 2 \mathrm{NH}$ ]; ${ }^{13} \mathrm{C}-\mathrm{NMR}: 55.2,55.8,87.0,113.1$, 122.9 (3), 128.4 (2), 129.1 (2), 131.5, 133.8, 140.0, 162.7 (2), 165.3, 170.2, 182.0. Anal. Calcd. for $\mathrm{C}_{19} \mathrm{H}_{18} \mathrm{FN}_{5} \mathrm{O}_{4} \mathrm{~S}_{2}: \mathrm{C}$, 49.24\%; H, 3.91\%; F, 4.10\%; N, 15.11\%; S, 13.84\%. Found: C, 49.30\%; H, 3.80\%; F, 4.20\%; N, 15.12\%; S, 13.84\%.

\section{N-(2,6-Dimethoxy-pyrimidin-4-yl)-4-[3-(3-fluoro-phenyl)-thi- oureido]benzene-sulfonamide (3b)}

This compound was obtained as brown crystals from ethanol; yield 87\%; m.p. $133.9^{\circ} \mathrm{C}$. IR: 3446, $3365(\mathrm{NH}), 3100$ (arom.), 2978, 2831 (aliph.), $1635(\mathrm{CN}), 1396,1182\left(\mathrm{SO}_{2}\right)$, 1274 (CS). ${ }^{1} \mathrm{HNMR}: \delta 3.80,3.83\left[2 \mathrm{~s}, 6 \mathrm{H}, 2 \mathrm{OCH}_{3}\right], 6.4[\mathrm{~s}$, $1 \mathrm{H}, \mathrm{H}$-pyrimidine], 6.9-8.4 [m, $8 \mathrm{H}, \mathrm{Ar}-\mathrm{H}], 9.8[\mathrm{~s}, 1 \mathrm{H}$, $\left.\mathrm{SO}_{2} \mathrm{NH}\right], 11.7$ [s, $2 \mathrm{H}, 2 \mathrm{NH}$ ]; ${ }^{13} \mathrm{C}-\mathrm{NMR}: 55.4,56.5,80.0$, 112.7, 120.6, 121.2, 123.7 (2), 128.1 (2), 132.6 (2), 137.0, 142.6, 163.0, 164.5, 164.9, 178.4, 179.8. Anal. Calcd. for $\mathrm{C}_{19} \mathrm{H}_{18} \mathrm{FN}_{5} \mathrm{O}_{4} \mathrm{~S}_{2}: \mathrm{C}, 49.24 \%$; H, 3.91\%; F, 4.10\%; N, 15.11\%; S, $13.84 \%$. Found: C, 49.50\%; H, 3.60\%; F, 4.50\%; N, $15.40 \%$; S, $13.80 \%$.

N-(2,6-Dimethoxy-pyrimidin-4-yl)-4-[3-(4-fluoro-phenyl)-thioureido]benzenesul-fonamide (3c)

This compound was obtained as brown crystals from ethanol; yield 90\%; m.p. > $360{ }^{\circ} \mathrm{C}$. IR: 3442, $3186(\mathrm{NH})$, 3062 (arom.), 2941, 2839 (aliph.), 1624 (CN), 1382, 1132 $\left(\mathrm{SO}_{2}\right), 1271(\mathrm{CS}) .{ }^{1} \mathrm{H}-\mathrm{NMR}: \delta 3.72,3.75\left[2 \mathrm{~s}, 6 \mathrm{H}, 2 \mathrm{OCH}_{3}\right]$, 6.4 [s, $1 \mathrm{H}, \mathrm{H}$ - pyrimidine], $6.9-8.8[\mathrm{~m}, 8 \mathrm{H}, \mathrm{Ar}-\mathrm{H}], 9.7[\mathrm{~s}$, $\left.1 \mathrm{H}, \mathrm{SO}_{2} \mathrm{NH}\right], 11.4[\mathrm{~s}, 2 \mathrm{H}, 2 \mathrm{NH}] .{ }^{13} \mathrm{C}-\mathrm{NMR}: \delta 55.4,55.7$, 84.1, 113.6 (2), 121.0 (2), 127.5 (2), 129.6 (2), 132.7, 133.8, 140.0, 158.6, 161.9, 165.8, 170.9, 182.3. Anal. Calcd. For $\mathrm{C}_{19} \mathrm{H}_{18} \mathrm{FN}_{5} \mathrm{O}_{4} \mathrm{~S}_{2}: \mathrm{C}, 49.24 \%$; H, 3.91\%; F, 4.10\%; N, 15.11\%; S, 13.84\%. Found: C, 49.10\%; H, 3.80\%; N, 15.30\%; S, 13.70\%.

\section{N-(2,6-Dimethoxy-pyrimidin-4-yl)-4-[3-(3-fluoro-4-meth-} oxy-phenyl)-thioureido]benzenesulfonamide (3d)

This compound was obtained as yellow crystals from ethanol; yield 88\%; m.p. $289^{\circ} \mathrm{C}$. IR: 3421, $3230(\mathrm{NH}), 3086$ (arom.), 2910, 2841 (aliph.), 1624 (CN), 1400, $1128\left(\mathrm{SO}_{2}\right)$, 1286 (CS). ${ }^{1} \mathrm{H}-\mathrm{NMR}: \delta 3.84,3.91,3.96\left[3 \mathrm{~s}, 9 \mathrm{H}, 3 \mathrm{OCH}_{3}\right]$, 6.4 [s, 1H, H-pyrimidine], 6.9-8.4 [m, 7H, Ar-H], 8.9 [s, $\left.1 \mathrm{H}, \mathrm{SO}_{2} \mathrm{NH}\right], 11.5$ [s, 2H, 2NH]; ${ }^{13} \mathrm{C}-\mathrm{NMR}: \delta$ 55.4, 55.6, 57.4, 79.6, 117.3 (2), 121.7 (2), 122.0, 129.7(2), 130.1, 134.7, 139.8, 140.9, 150.8, 160.2, 162.9, 172.0, -183.3. Anal. Calcd. For $\mathrm{C}_{20} \mathrm{H}_{20} \mathrm{FN}_{5} \mathrm{O}_{5} \mathrm{~S}_{2}: \mathrm{C}, 48.67 \% ; \mathrm{H}, 4.08 \%$; F, 3.85\%; N, 14.19\%; O, 16.21\%; S, 12.99\%. Found: C, 48.50\%; H, 4.10\%; F, 3.30\%; N, 14.20\%; S, 12.70\%.

\section{N-(2,6-Dimethoxy-pyrimidin-4-yl)-4-[3-(4-fluoro-2-ni- tro-phenyl)-thioureido]benzenesulfonamide (3e)}

This compound was obtained as yellow crystals from ethanol; yield 86\%; m.p. $143.5{ }^{\circ} \mathrm{C}$. IR: 3421, $3197(\mathrm{NH})$, 3062 (arom.), 2936, 2839 (aliph.), 1625 (CN), 1384, 1132 $\left(\mathrm{SO}_{2}\right), 1269$ (CS). ${ }^{1} \mathrm{H}-\mathrm{NMR}:$ 83.80, 3.84 [2 s, 6H, 2OCH 3 , $6.5[\mathrm{~s}, 1 \mathrm{H}, \mathrm{H}$-pyrimidine $], 6.9-8.4[\mathrm{~m}, 7 \mathrm{H}, \mathrm{Ar}-\mathrm{H}], 9.8$ [s, $\left.1 \mathrm{H}, \mathrm{SO}_{2} \mathrm{NH}\right], 10.4,11.0[2 \mathrm{~s}, 2 \mathrm{H}, 2 \mathrm{NH}] .{ }^{13} \mathrm{C}-\mathrm{NMR}$ : 55.4, 56.5, 79.8, 112.7, 121.4, 125.5 (2), 127.8 (2), 128.1 (2), 133.6, 144.0, 144.9, 153.1, 155.3, 165.7, 170.2, 178.8 . Anal. Calcd. For $\mathrm{C}_{19} \mathrm{H}_{19} \mathrm{FN}_{6} \mathrm{O}_{6} \mathrm{~S}_{2}$ : C, 44.70\%; H, 3.75\%; F, $3.72 \%$; N, 16.46\%; S, $12.56 \%$. Found: C, 44.60\%; H, 3.50\%; F, 3.70\%; N, 16.40\%; S, $12.60 \%$.

\section{N-(2,6-Dimethoxy-pyrimidin-4-yl)-4-[3-(2,3,5,6-tetra-} fluoro-pyridin-4-yl)-thioureido]benzenesulfonamide (4a) This compound was obtained as brown crystals from ethanol; yield 87\%; m.p. $281.7^{\circ}$ C.IR: $3400,3192(\mathrm{NH})$, 3057 (arom.), 2931, 2871 (aliph.), 1620 (CN), 1386, 1128 $\left(\mathrm{SO}_{2}\right), 1257$ (CS). ${ }^{1} \mathrm{H}-\mathrm{NMR}: \delta 3.80,3.84\left[2 \mathrm{~s}, 6 \mathrm{H}, 2 \mathrm{OCH}_{3}\right]$, $6.1[\mathrm{~s}, 1 \mathrm{H}, \mathrm{H}$-pyrimidine], $6.7-8.2[\mathrm{~m}, 4 \mathrm{H}, \mathrm{Ar}-\mathrm{H}], 10.3$ $\left[\mathrm{s}, 1 \mathrm{H}, \mathrm{SO}_{2} \mathrm{NH}\right], 11.7[\mathrm{~s}, 2 \mathrm{H}, 2 \mathrm{NH}] ;{ }^{13} \mathrm{C}-\mathrm{NMR}: \delta 55.4$, 55.6, 81.2, 121.8 (2),128.7 (2), 130.2(2), 137.1, 140.8, 143.0, 144.5 (2), 161.4, 161.9, 169.7, 184.6. Anal. Calcd. For $\mathrm{C}_{18} \mathrm{H}_{14} \mathrm{~F}_{4} \mathrm{~N}_{6} \mathrm{O}_{4} \mathrm{~S}_{2}: \mathrm{C}, 41.60 \%$; $\mathrm{H}, 2.42 \%$; $\mathrm{F}, 14.60 \%$; N, $16.30 \%$; S, $12.40 \%$. Found: C, $41.60 \%$; H, $2.42 \%$; F, $14.60 \%$; N, $16.30 \%$; S, $12.40 \%$.

N-(2,6-Dimethoxy-pyrimidin-4-yl)-4-[3-(5-trifluoromethyl-[1, 3, 4]thiadiazol-2-yl)-thioureido]-benzenesulfonamide (4b) This compound was obtained as brown crystals from ethanol; yield 86\%; m.p. $276.7{ }^{\circ} \mathrm{C}$. IR: 3400, 3201(NH), 3045 (arom.), 2923, 2801 (aliph.), 1622 (CN),1386,1130 $\left(\mathrm{SO}_{2}\right), 1323(\mathrm{CS}) .{ }^{1} \mathrm{H}-\mathrm{NMR}: \delta 3.80,3.81\left[2 \mathrm{~s}, 6 \mathrm{H}, 2 \mathrm{OCH}_{3}\right]$, $6.1[\mathrm{~s}, 1 \mathrm{H}, \mathrm{H}$-pyrimidine],6.9-8.4 [m, 4H, Ar-H], 10.1 [s, $\left.1 \mathrm{H}, \mathrm{SO}_{2} \mathrm{NH}\right], 10.3,12.0[2 \mathrm{~s}, 2 \mathrm{H}, 2 \mathrm{NH}] ;{ }^{13} \mathrm{C}-\mathrm{NMR}$ : 56.2, 56.7, 81.6, 117.2, 120.8 (2), 130.7 (2), 134.6, 143.0, 151.1, 154.6, 161.7, 163.9, 173.0, 182.8. Anal. Calcd. for $\mathrm{C}_{16} \mathrm{H}_{14} \mathrm{~F}_{3} \mathrm{~N}_{7} \mathrm{O}_{4} \mathrm{~S}_{3}: \mathrm{C}, 36.85 \% ; \mathrm{H}, 2.71 \%$; F, 10.93\%; N, $18.80 \%$; S, $18.45 \%$. Found: C, $36.70 \%$; H, 2.90\%; F, 10.70\%; N, $18.90 \%$; S, 18.90\%.

\section{N-(2,6-Dimethoxy-pyrimidin-4-yl)-4-[3-(6-fluoro-benzothi-} azol-2-yl)-thioureido]-benzenesulfonamide (4c)

This compound was obtained as brown crystals from ethanol; yield 92\%; m.p. $179.7{ }^{\circ} \mathrm{C}$. IR: 3415, $3310(\mathrm{NH})$, 
3075 (arom.), 2978, 2841 (aliph.), 618 (CN), 1311, $1195\left(\mathrm{SO}_{2}\right), 1274$ (CS). ${ }^{1} \mathrm{H}-\mathrm{NMR}: \delta 3.64,3.66[2 \mathrm{~s}, 6 \mathrm{H}$, $2 \mathrm{OCH}_{3}$ ], 6.5 [s, 1H, H-pyrimidine], 6.9-8.5 [m, 7H, Ar$\mathrm{H}], 9.7\left[\mathrm{~s}, 1 \mathrm{H}, \mathrm{SO}_{2} \mathrm{NH}\right], 11.8,12.4[2 \mathrm{~s}, 2 \mathrm{H}, 2 \mathrm{NH}] .{ }^{13} \mathrm{C}-\mathrm{NMR}$ : 55.4, 55.8, 83.7, 109.1, 112.0, 119.2, 123.7 (2), 128.1 (2), 132.8, 134.2, 139.9, 147.1, 156.6, 157.1, 165.3, 174.0, 175.1, 183.2. Anal. Calcd. for $\mathrm{C}_{20} \mathrm{H}_{17} \mathrm{FN}_{6} \mathrm{O}_{4} \mathrm{~S}_{3}$ : C, 46.14\%; H, 3.29\%; F, 3.65\%; N, 16.14\%; S, 18.48\%. Found: C, $46.20 \%$; H, 3.40\%; F, 3.60\%; N, 16.30\%; S, $18.48 \%$.

N-(2,6-Dimethoxy-pyrimidin-4-yl)-4-[3-(4-trifluoromethyl-2-oxo-2H-chromen-7-yl)-thioureido]-benzenesulfonamide (4d)

This compound was obtained as brown crystals from ethanol; yield 81\%; m.p. $209.7{ }^{\circ} \mathrm{C}$. IR: 3454, 3361, 3250 (NH), 3100 (arom.), 2970, 2861 (aliph.), 1708 (CO), 1635 (CN),1350,1165 ( $\left.\mathrm{SO}_{2}\right), 1286$ (CS). ${ }^{1} \mathrm{H}-\mathrm{NMR}: 3.80,3.82$ [2 s, 6H, 20CH 3 ], 6.3 [s, 1H, H -pyrimidine], 6.8-8.0 $\left[\mathrm{m}, 8 \mathrm{H}, \mathrm{Ar}-\mathrm{H}+\mathrm{H}\right.$-chromene], $9.8\left[\mathrm{~s}, 1 \mathrm{H}, \mathrm{SO}_{2} \mathrm{NH}\right]$, 11.4 [s,2H, 2NH]; ${ }^{13} \mathrm{C}-\mathrm{NMR}: 55.4,55.6,80.6,107.2$, 112.6 (2), 121.3 (2), 126.1 (3), 129.0 (2), 133.0 (2), 140.5, 154.5 (2), 157.0, 159.8, 165.2, 174.6, 180.3. Anal. Calcd. for $\mathrm{C}_{23} \mathrm{H}_{18} \mathrm{~F}_{3} \mathrm{~N}_{5} \mathrm{O}_{6} \mathrm{~S}_{2}$ : C, 47.50\%; $\mathrm{H}, 3.12 \%$; F, 9.80\%; N, 12.04\%; S, 11.03\%. Found:C, 47.70\%; H, 3.50\%; F, 9.70\%; N, $12.30 \%$;, $11.20 \%$.

\section{Antimicrobial activity assay}

All microbial strains were provided from culture collection of the Regional Center for Mycology and Biotechnology (RCMB), Al-Azhar University, Cairo, Egypt. The antimicrobial activity was investigated on a dozen of newly synthesized compounds in order to increase the selectivity of these derivatives towards test microorganisms using well diffusion method [42]. Briefly, $100 \mu \mathrm{L}$ of the test bacteria/fungi were grown in $10 \mathrm{~mL}$ of fresh media until they reached a count of approximately $10^{8}$ cells $/ \mathrm{mL}$ for bacteria or $10^{5}$ cells $/ \mathrm{mL}$ for fungi. One hundred $\mu \mathrm{L}$ of each sample (at $1 \mathrm{mg} / \mathrm{mL}$ ) was added to each well (10 $\mathrm{mm}$ diameter holes cut in the agar gel). The plates were incubated for $24-48 \mathrm{~h}$ at $37{ }^{\circ} \mathrm{C}$ (for bacteria and yeast) and for $48 \mathrm{~h}$ at $28{ }^{\circ} \mathrm{C}$ (for filamentous fungi). After incubation, the microorganism's growth was observed. Ampicillin and gentamycin were used as standard antibacterial drugs while amphotricin B was used as standard antifungal drug. The resulting inhibition zone diameters were measured in millimeters and used as criterion for the antimicrobial activity. If an organism is placed on the agar it will not grow in the area around the well if it is susceptible to the chemical. This area of no growth around the disc is known as a zone of inhibition. The size of the clear zone is proportional to the inhibitory action of the compound under investigation. Solvent controls (DMSO) were included in every experiment as negative controls. DMSO was used for dissolving the tested compounds and showed no inhibition zones, confirming that it has no influence on growth of the tested microorganisms. The active compounds were further investigated to determine their antimicrobial activity expressed in terms of minimum inhibitory concentration (MIC) using the modified agar well diffusion method that mentioned above. Concentrations between 0.1 and $1000 \mu \mathrm{g} / \mathrm{mL}$ of each active compound were tested and compared with standard drugs. The MIC was then determined as the lowest concentration inhibiting growth of the organism after $24-48 \mathrm{~h}$.

\section{Antitumor activity assay}

The tested human carcinoma cell lines were obtained from the American Type Culture Collection (ATCC, Rockville, MD). The cells were grown on RPMI-1640 medium supplemented with $10 \%$ inactivated fetal calf serum and $50 \mu \mathrm{g} / \mathrm{mL}$ gentamycin. The cells were maintained at $37{ }^{\circ} \mathrm{C}$ in a humidified atmosphere with $5 \% \mathrm{CO}_{2}$ and were sub-cultured two to three times a week.

For antitumor assays, the tumor cell lines were suspended in medium at cell density of $5 \times 10^{4}$ cells/well in Corning $^{\circledR}$ 96-well tissue culture plates, then incubated for $24 \mathrm{~h}$. The tested compounds were then added into 96-well plates (six replicates) to achieve eight concentrations for each compound. Six vehicle controls with media or $0.5 \%$ DMSO were run for each 96 well plate as a control. After incubating for $24 \mathrm{~h}$, the numbers of viable cells were determined by the MTT assay $[43,44]$. Briefly, the media was removed from the 96-well plate and replaced with $100 \mu \mathrm{L}$ of fresh culture RPMI 1640 medium without phenol red then $10 \mu \mathrm{L}$ of the $12 \mathrm{mM}$ MTT stock solution (5 mg of MTT in $1 \mathrm{~mL}$ of PBS) to each well including the untreated controls. The 96 well plates were then incubated at $37{ }^{\circ} \mathrm{C}$ and $5 \% \mathrm{CO}_{2}$ for $4 \mathrm{~h}$. An $85 \mu \mathrm{L}$ aliquot of the media was removed from the wells, and $50 \mu \mathrm{L}$ of DMSO was added to each well and mixed thoroughly with the pipette and incubated at $37^{\circ} \mathrm{C}$ for $10 \mathrm{~min}$. Then, the optical density was measured at $590 \mathrm{~nm}$ with the microplate reader (SunRise, TECAN, Inc, USA) to determine the number of viable cells and the percentage of viability was calculated as $[1-(\mathrm{ODt} / \mathrm{ODc})] \times 100 \%$ where ODt is the mean optical density of wells treated with the tested sample and ODc is the mean optical density of untreated cells. The relation between surviving cells and drug concentration is plotted to get the survival curve of each tumor cell line after treatment with the specified compound. The $50 \%$ inhibitory concentration $\left(\mathrm{IC}_{50}\right)$, the concentration required to cause toxic effects in $50 \%$ of intact cells, was estimated from graphic plots of the dose response curve for each conc. using Graphpad Prism software (San Diego, CA, USA) [31]. 


\section{Molecular docking}

All the molecular modeling studies were carried out on an Intel Pentium 1.6 GHz processor, $512 \mathrm{MB}$ memory with Windows XP operating system using Molecular Operating Environment (MOE, 10.2008) software. All the minimizations were performed with MOE until a RMSD gradient of $0.05 \mathrm{kcal} \mathrm{mol}^{-1} \AA^{-1}$ with MMFF94X force field and the partial charges were automatically calculated. The protein data bank file (PDB:3WI6) was selected for this purpose. The file contains MK-2 enzyme Co-crystalized with a ligand obtained from protein data bank. The enzyme was prepared for docking studies where: (i) Ligand molecule was removed from the enzyme active site. (ii) Hydrogen atoms were added to the structure with their standard geometry. (iii) MOE Alpha Site Finder was used for the active sites search in the enzyme structure and dummy atoms were created from the obtained alpha spheres. (iv) The obtained model was then used in predicting the ligand enzymes interactions at the active site.

\section{Authors' contributions}

MM Ghorab, MS Alsaid and MSA El-Gaby designed and carried out synthetic schemes, MM Elaasser carried out biological screening and YM Nissan carried out molecular docking study. All authors read and approved the final manuscript.

\section{Author details}

1 Pharmacognosy Department, College of Pharmacy, King Saud University, P.O. Box 2457, Riyadh 11451, Saudi Arabia. ${ }^{2}$ Department of Drug Radiation Research, National Center for Radiation Research and Technology, Nasr City, Cairo 113701, Egypt. ${ }^{3}$ Department of Chemistry, Faculty of Science, Al-Azhar University at Assiut, Assiut 71524, Egypt. ${ }^{4}$ The Regional Center for Mycology and Biotechnology, Al-Azhar University, Cairo, Egypt. ${ }^{5}$ Department of Pharmaceutical Chemistry, Faculty of Pharmacy, Cairo University, Cairo, Egypt.

\section{Acknowledgements}

The authors are thankful to the Deanship of the Scientific Research and Research Center, College of Pharmacy, King Saud University, Riyadh, Saudi Arabia.

\section{Competing interests}

The authors declare that they have no competing interests.

\section{Ethics approval and consent to participate}

No human subjects are involved in this research.

\section{Funding}

Deanship of Scientific Research and Research Center, College of Pharmacy, King Saud University, Riyadh.

\section{Publisher's Note}

Springer Nature remains neutral with regard to jurisdictional claims in published maps and institutional affiliations.

Received: 15 February 2017 Accepted: 27 March 2017

Published online: 07 April 2017

\section{References}

1. Böhm H-J, Banner D, Bendels S, Kansy M, Kuhn B, Müller K, Obst-Sander U, Stahl M (2004) Fluorine in medicinal chemistry. ChemBioChem 5:637-643

2. Müller K, Faeh C, Diederich F (2007) Fluorine in pharmaceuticals: looking beyond intuition. Science 317:1881-1886
3. Shah P, Westwell AD (2007) The role of fluorine in medicinal chemistry. J Enzyme Inhib Med Chem 22:527-540

4. Purser S, Moore PR, Swallow S, Gouverneur V (2008) Fluorine in medicinal chemistry. Chem Soc Rev 37:320-330

5. Hu J, Zeng Y (2015) Recent advances in green fluorine chemistry. Rep Org Chem 5:19-39

6. Petrov VA (2009) Perluorinated nonaromatic heterocycles. In: Petrov VA (ed) Fluorinated heterocyclic compounds: Synthesis, chemistry and applications. Wiley, New York

7. Isanbor C, O'Hagan D (2006) Fluorine in medicinal chemistry: a review of anti-cancer agents. J Fluor Chem 127:303-319

8. Kirk KL (2006) Fluorine in medicinal chemistry: recent therapeutic applications of fluorinated small molecules. J Fluor Chem 127:1013-1029

9. Li H-Q, Lv P-C, Yan T, Zhu HL (2009) Urea derivatives as anticancer agents. Anticancer Agents Med Chem 9:471-480

10. Li J, Tan J, Chen L, Zhang J, Shen X, Mei C, Fu L, Lin L, Ding J, Xiong B, Xiong $X$, Liu H, Luo X, Jiang H (2006) Design, synthesis and antitumor evaluation of a new series of $\mathrm{N}$-substituted-thiourea derivatives. Acta Pharmacol Sin 27:1259-1271

11. Xiong X, Liu H, Fu L, Li L, Li J, Luo X, Mei C (2008) Antitumor activity of a new $\mathrm{N}$-substituted thiourea derivative, an EGFR signaling-targeted inhibitor against a panel of human lung cancer cell lines. Chemotherapy 54:463-474

12. Li H-Q, Yan T, Yang Y, Shi L, Zhou C-F, Zhu H-L (2010) Synthesis and structureactivity relationships of $\mathrm{N}$-benzyl-N-(X-2-hydroxybenzyl)-N'-phenylureas and thioureas as antitumor agents. Bioorgan Med Chem 18:305-313

13. Lv P-C, Li H-Q, Sun J, Zhou Y, Zhu HL (2010) Synthesis and biological evaluation of pyrazole derivatives containing thiourea skeleton as anticancer agents. Bioorg Med Chem 18:4606-4614

14. Napper AD, Hixon J, McDonagh T, Keavey K, Pons J-F, Barker J, Yau WT, Amouzegh P, Flegg A, Hamelin E, Thomas RJ, Kates M, Jones S, Navia MA, Saunders JO, DiStefano PS, Curtis R (2005) Discovery of indoles as potent and selective inhibitors of the deacetylase SIRT1. J Med Chem 48:8045-8054

15. Huang $H$, Chen $Q$, Ku X, Meng L, Lin L, Wang X, Zhu C, Wang Y, Chen Z, Li M, Jiang H, Chen K, Ding J, Liu H (2010) A series of alpha-heterocyclic carboxaldehyde thiosemicarbazones inhibit topoisomerase II alpha catalytic activity. J Med Chem 53:3048-3064

16. Ziegler-Skylakakis K, Rossberger S, Andrae U (1985) Thiourea induces DNA repair synthesis in primary rat hepatocyte cultures and gene mutations in V79 Chinese hamster cells. Arch Toxicol 58:5-9

17. Peng $H$, Liang $Y$, Chen $L, F u L$, Wang $H, H e H$ (2011) Efficient synthesis and biological evaluation of 1,3-benzenedicarbonyl dithioureas. Bioorg Med Chem Lett 21:1102-1104

18. Du X, Hansell E, Engel JC, Caffrey CR, Cohen FE, McKerrow JH (2000) Aryl ureas represent a new class of anti-trypanosomal agents. Chem Biol 7:733-742

19. Sun C, Huang H, Feng M, Shi X, Zhang X, Zhou P (2006) A novel class of potent influenza virus inhibitors: polysubstituted acylthiourea and its fused heterocycle derivatives. Bioorg Med Chem Lett 16:162-166

20. Liav A, Angala SK, Brennan PJ, Jackson M (2008) N-D-aldopentofuranosyl$\mathrm{N}^{\prime}$-[p-(isoamyloxy)phenyl]-thiourea derivatives, potential anti-TB therapeutic agents. Bioorg Med Chem Lett 18:2649-2651

21. De Clercq E (2001) Hamao Umezawa memorial award lecture: an Odyssey in the viral chemotherapy field. Int J Antimicrob Agents 18:309-328

22. De Clercq E (1997) In search of a selective antiviral chemotherapy. Clin Microbiol Rev 10:674-693

23. Shah SSA, Rivera G, Ashfaq M (2013) Recent advances in medicinal chemistry of sulfonamides. Rational design as anti-tumoral, anti-bacterial and anti-inflammatory agents. Mini Rev Med Chem 13:70-86

24. Parasca OM, Gheață F, Pânzariu A, Geangalău I, Profire L (2012) Importance of sulfonamide moiety in current and future therapy. Rev medicochirurgicală a Soc Medici şi Nat din laşi 117:558-564

25. Vullo D, De Luca V, Scozzafava A, Carginale V, Rossi M, Supuran CT, Capasso C (2013) The extremo-a-carbonic anhydrase from the thermophilic bacterium Sulfurihydrogenibium azorense is highly inhibited by sulfonamides. Bioorg Med Chem 21:4521-4525

26. Wilson CO, Gisvold O, Block JH (2004) Anti Infective Agents. In: Block J, Beale JM (eds) Wilson and Gisvold's Textbook of organic medicinal and pharmaceutical chemistry, 11th edn. Lippincott Williams and Wilkins, Philadelphia 
27. Levin JI, Chen JM, Du MT, Nelson FC, Killar LM, Skala S, Sung A, Jin G, Cowling R, Barone D, March CJ, Mohler KM, Black RA, Skotnicki JS (2002) Anthranilate sulfonamide hydroxamate TACE inhibitors. Part 2: SAR of the acetylenic $\mathrm{P} 1^{\prime}$ group. Bioorg Med Chem Lett 12:1199-1202

28. Kim DK, Lee JY, Lee N, Ryu DH, Kim JS, Lee S, Choi JY, Ryu JH, Kim NH, Im GJ, Choi WS, Kim TK (2001) Synthesis and phosphodiesterase inhibitory activity of new sildenafil analogues containing a carboxylic acid group in the 5'-sulfonamide moiety of a phenyl ring. Bioorg Med Chem 9:3013-3021

29. Hu B, Ellingboe J, Han S, Largis E, Lim K, Malamas M, Mulvey R, Niu C, Oliphant A, Pelletier J, Singanallore T, Sum FW, Tillett J, Wong V (2001) Novel (4-piperidin-1-yl)-phenyl sulfonamides as potent and selective human beta(3) agonists. Bioorg Med Chem 9:2045-2059

30. Ma T, Fuld AD, Rigas JR, Hagey AE, Gordon GB, Dmitrovsky E, Dragnev $\mathrm{KH}$ (2012) A phase I trial and in vitro studies combining ABT-751 with carboplatin in previously treated non-small cell lung cancer patients. Chemotherapy 58:321-329

31. Dekker M (2001) Design and synthesis of amprenavir, a novel HIV protease inhibitor. In: Ogden RC, Flexner CW (ed) In protease inhibitors in AIDS therapy. Marcel Dekker, New York

32. Roush WR, Gwaltney SL, Cheng J, Scheidt KA, McKerrow JH, Hansell E (1998) Vinyl sulfonate esters and vinyl sulfonamides: potent, irreversible inhibitors of cysteine proteases. J Am Chem Soc 120:10994-10995

33. El-Gaby MSA, Ismail ZH, Abdel-Gawad SM, Aly HM, Ghorab MM (2009) Synthesis of thiazolidine and thiophene derivatives for evaluation as anticancer agents. Phosphorus Sulfur Silicon Relat Elem 184:2645-2654

34. El-Gaby MSA, Hussein AM, Abu-Shanab FAM, Abdel-Raheim MAM (2003) Preparation of some hitherto unknown thiosemicarbazide, thiourea, bisthiourea, benzoazole derivatives bearing quinoxalin-2-yl moiety and evaluate their biological activity. Afinidad Rev química teórica y Apl 60:358-368

35. El-Gaby MSA, Micky JA, Taha NM, El-Sharief S, Marwa AM (2002) Antimicrobial activity of some novel thiourea, hydrazine, fused pyrimidine and 2-(4-substituted)anilinobenzoazole derivatives containing sulfonamido moieties. J Chin Chem Soc 49:407-414
36. Sharma S (1989) Isothiocyanates in heterocyclic synthesis. Sulfur Rep 8:327-454

37. Mukerjee AK, Ashare R (1991) Isothiocyanates in the chemistry of heterocycles. Chem Rev 91:1-24

38. Ahmed EM, Taha NM, El-gawad SMA, Nady NMS (2011) Novel thiourea, quinazoline, thiazolidine, thieno[2,3-d]-pyrimidine, 4-thiazolidinone, pyrrole, pyrrolo[2,3-d]pyrimidine derivatives containing sulfamoyl moiety. Der Chem Sin 2:197-210

39. Kotlyarov A, Neininger A, Schubert C, Eckert R, Birchmeier C, Volk HD, Gaestel M (1999) MAPKAP kinase 2 is essential for LPS-induced TNF-alpha biosynthesis. Nat Cell Biol 1:94-97

40. Haddad JJ (2001) VX-745 (vertex pharmaceuticals). Curr Opin Investig Drugs 2:1070-1076

41. Lin S, Lombardo M, Malkani S, Hale JJ, Mills SG, Chapman K, Thompson JE, Zhang WX, Wang R, Cubbon RM, O'Neill EA, Luell S, Carballo-Jane E, Yang L (2009) Novel 1-(2-aminopyrazin-3-yl)methyl-2-thioureas as potent inhibitors of mitogen-activated protein kinase-activated protein kinase 2 (MK-2). Bioorg Med Chem Lett 19:3238-3242

42. Ibrahim HS, Eldehna WM, Abdel-Aziz HA, Elaasser MM, Abdel-Aziz MM (2014) Improvement of antibacterial activity of some sulfa drugs through linkage to certain phthalazin-1(2H)-one scaffolds. Eur J Med Chem 85:480-486

43. Riyadh SM, Gomha MS, Mahmmoud EA, Elaasser MM (2015) Synthesis and anticancer activities of thiazoles, 1,3-thiazines, and thiazolidine using chitosan-grafted-poly(vinylpyridine) as basic catalyst. Heterocycles 91:1227-1243

44. Mosmann T (1983) Rapid colorimetric assay for cellular growth and survival, application to proliferation and cytotoxicity assays. J Immunol Methods 65:55-63

\section{Submit your manuscript to a SpringerOpen ${ }^{\odot}$ journal and benefit from:}

- Convenient online submission

- Rigorous peer review

- Immediate publication on acceptance

- Open access: articles freely available online

- High visibility within the field

- Retaining the copyright to your article

Submit your next manuscript at springeropen.com 